\title{
Searching for Statesmanship: a Corpus-Based Analysis of a Translated Political Discourse
}

\author{
Henry Jones \\ University of Manchester, UK \\ henry.jones@manchester.ac.uk
}

\begin{abstract}
With its connotations of superior moral integrity, exceptional leadership qualities and expertise in the science of government, the modern ideal of statesmanship is most commonly traced back to the ancient Greek concept of $\pi 0 \lambda$ เ $\tau$ เxós (politikos) and the work of Plato and Aristotle in particular. Through an analysis of a large corpus of modern English translations of political works, built as part of the AHRC Genealogies of Knowledge project (http://genealogiesofknowledge.net/), this case-study aims to explore patterns that are specific to this translated discourse, with a view to understanding the crucial role played by translators in shaping its development and reception in society. It ultimately seeks to argue that the model of statesmanship presented in translations from ancient Greek is just as much a product of the receiving culture (and the social anxieties of Victorian Britain especially) as it is inherited from the classical world.
\end{abstract}

\section{Keywords}

translation - statesmanship - democracy - Plato - Aristotle - classical Greece

\section{Introduction: Defining Statesmanship ${ }^{1}$}

We have a great many politicians in the country, perhaps as many as the country requires. I should not wish to ask for a larger supply of these; but

1 This research was supported by the Arts and Humanities Research Council (Grant number: $\mathrm{AH} / \mathrm{Mo10007/1).}$ 
there is a wide difference between the politician and the statesman. A politician, for example, is a man who thinks of the next election; while the statesman thinks of the next generation. The politician thinks of the success of his party, the statesman of the good of his country. ${ }^{2}$

Written in 1870, the above extract is from the opening paragraphs of an essay entitled Wanted, A Statesman! by the American cultural commentator, James Freeman Clarke. Reflecting on the state of the nation in the wake of the Civil War, the author makes an impassioned plea for greater evidence of 'statesmanship' in the conduct of the public men of his day. As the lines cited explain, this argument rests on a fundamental distinction between those deserving only of the label 'politician' and those categorised as 'statesmen'. The politician, on the one hand, is framed as a self-interested character whose actions are largely guided, not by what might be best for his country, but rather by what might get him (re-)elected. His decisions are hence characterised by 'short-termism' - a myopic focus on immediate problems to the detriment of long-term interests and concerns - given that the needs of future generations are all too frequently demoted in favour of attempts to flatter and appease his contemporaries. According to Clarke, a politician is also cowardly refusing to take risks whose outcomes could damage his current popularity, and ever willing to abandon all ideological principles if the tide of current opinion is against him. Indeed, he is most often happy enough to drift along on the sea of human history, rather than attempt to steer a new course for the state. ${ }^{3}$

The statesman, by contrast, is viewed as a higher class of political actor, wholly and absolutely dedicated to his country. Not only is he able to foresee coming events, but he is also sufficiently skilled in the art of politics to 'put his hand on the rudder' and guide the ship of the state towards safety and prosperity. ${ }^{4} \mathrm{He}$ is idealistic and stands by his principles in the face of adversity, but pragmatic too and capable of weighing up both sides of an argument. Most importantly, however, while 'the politician believes in the newspaper, the statesman believes in the people': he is not interested in what will merely look good in headlines, but instead in taking steps which will concretely improve the well-being of the nation. ${ }^{5}$ The seventh US president, Andrew Jackson, is highlighted by Clarke as an example of such a man, as is the then recently assassinated Abraham Lincoln.

2 J.F. Clarke, 'Wanted, A Statesman!', Old and New Magazine, 2 (December 1870), p. 644.

3 Clarke, 'Wanted, A Statesman!', pp. 644-6.

4 Clarke, 'Wanted, A Statesman!', p. 645.

5 Clarke, 'Wanted, A Statesman!', p. 645. 
Clarke's description of the statesman can be seen to accord with that presented across the Atlantic in essays by many British writers of the era: Jelinger Symonds, for example, portrays George Grote as 'the most clear-headed and righteous statesman' in parliament, 'a man [...] far beyond his times', whose actions are contrasted with 'the pungent and illogical raillery' of his peers. ${ }^{6}$ Clarke's model also concurs with more up-to-date dictionary definitions of the term, such as that currently proposed by the Oxford English Dictionary: '[a] person (esp. a man) who takes a leading part in the affairs of a state; a skilled, experienced and respected politician'. ${ }^{7}$ Here too the possession of political skill and ability is made an essential attribute of the modern statesman: unlike those belonging to the broader category of 'politicians', this is not someone who is simply 'keenly interested in politics' and/or 'professionally involved' in the organisation and management of society. ${ }^{8}$ A statesman's activities and interventions are based on a deep understanding and theoretical knowledge of political economy: indeed, it is this extraordinary expertise in the science of government that distinguishes the statesman from other political agents and that, inevitably, makes him a 'very rare bird', a source of individual - rather than collective - political power. ${ }^{9}$

Most significantly, it is also these exceptional attributes that legitimise the statesman's authority and influence over other members of society. ${ }^{10}$ In both Clarke and Symonds' texts, as well as in other more recent discussions of the concept, the statesman is explicitly not an ordinary citizen, but an 'outstanding individual', belonging to an exclusive political and social elite who are by nature better equipped to rule. ${ }^{11}$ Clearly, then, the compatibility of statesmanship and modern democratic thinking is uneasy: while the former concept 'presupposes qualitative differences' between citizens and suggests that 'some people are, because of their wisdom and virtue, more suited for political

6 J. Symonds, Sir Robert Peel as a Type of Statesmanship (London: Longman, 1856), p. 106.

7 OED Online, 'statesman, n.1' (Oxford: Oxford University Press, 2018), http://www.oed .com/view/Entry/189271 (accessed August 09, 2018).

8 OED Online, 'politician, n. and adj.' (Oxford: Oxford University Press, 2018), http://www .oed.com/view/Entry/146891 (accessed August 09, 2018).

9 P. Overeem, 'Aristotle's Politikos: Statesmanship, Magnanimity, and the Rule of the Many', in E. Cohen de Lara and R. Brouwer (eds.), Aristotle's Practical Philosophy: On the relationship between his ethics and politics (Cham: Springer International Publishing, 2018), pp. 36-7. See also P. Overeem and F. Bakker, 'Statesmanship Beyond the Modern State', Perspectives on Political Science (2016).

10 M. Nichols, Citizens and Statesmen: A Study of Aristotle's Politics (Lanham, MA: Rowman and Littlefield Publishers, 1992), p. 1.

11 See also L. Strauss, The City and Man (Chicago: University of Chicago Press, 1964), p. 37. 
leadership than others', the latter is based on an ideal of political equality for all. ${ }^{12}$ In fact, for this reason, the statesman is today more commonly associated with aristocratic politics and the belief that "political inequality is ultimately justified by the natural inequality among men". ${ }^{13}$

Of particular interest to the focus of this article, however, is the way in which the discourse of statesmanship appears to have been thanded down to us from the ancients'.14 Specifically, as Overeem has noted, this political ideal

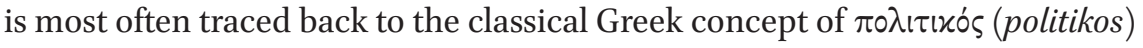
and the work of Plato and Aristotle in particular. ${ }^{15}$ Indeed, as this article will demonstrate by means of a corpus-based approach developed as part of the Genealogies of Knowledge project, discussions of the 'statesman', 'statesmen' and 'statesmanship' seem to pervade English-language translations of classical Greek texts to an extent unparalleled in other sources of political theory interrogated and/or translated over the past 170 years. Yet, the apparently direct continuity of this discourse across languages and over the centuries belies the complexity of meanings deployed within these source materials and the crucial role translators have played in shaping its development and reception in society. Thus, this article aims to explore not only patterns within this translated discourse, but also the key processes of translation involved in the construction of modern understandings of ancient Greek statesmanship. In the final sections, I then seek to explain the ideological implications and motivations for establishing such equivalences.

\section{$2 \quad$ Situating the Present Study: the Genealogies of Knowledge Project}

Before presenting this analysis, it is important to first situate the study within the context of the Genealogies of Knowledge $(\mathrm{GoK})$ project of which it forms a part, as well as to introduce in more detail the methods and data on which the investigation is based. To begin with the research context, GoK is an AHRC-funded, multi-disciplinary project focused on the role of translation and other sites of (re-)mediation in the evolution, transformation and contestation of political and scientific discourse across languages, cultures and centuries. Specifically, a core objective of our programme is to build a set of large and

\footnotetext{
12 Overeem and Bakker, 'Statesmanship Beyond the Modern State', p. 3.

13 Strauss, The City and Man, p. 38. See also Nichols, Citizens and Statesmen, p. 4; Overeem and Bakker, 'Statesmanship Beyond the Modern State', p. 3; R. Ruderman, 'Democracy and the Problem of Statesmanship', The Review of Politics, 59, no. 4 (1997), p. 759.

14 Overeem, 'Aristotle's Politikos', p. 36.

15 Overeem, 'Aristotle's Politikos', p. 36.
} 
diverse electronic corpora containing as many different translations, commentaries and critical editions of texts relevant to these themes as possible, produced at different times, in different languages and by different writers. We then provide the research community with controlled access to these resources from remote locations via a specially developed suite of online corpus analysis tools, available free of charge on our project website. ${ }^{16}$ This software includes a 'Keyword-in-Context' (KWIC) concordancer as well as a series of 'plugins' which allow for the graphical visualisation of linguistic patterns. ${ }^{17}$

The specific GoK corpus on which the present study is based is the Modern English corpus, which currently contains a total of over 300 texts and 18.6 million words. Well over a third ( 8.8 million words) of this collection of English-language texts are direct translations from classical Greek, published from the mid-nineteenth century through to the present day, but the corpus also contains a growing number of translations from Latin (3.8 million words), as well as translations of political and scientific theory written by more contemporary authors (e.g. Hegel, Marx, Wittgenstein, Foucault and Balibar), all produced within the same time period. We additionally include several commentaries on ancient texts such as those produced by George Grote in the 1880 s, and a number of original writings (2.6 million words) deemed of particular relevance to the development of political and scientific discourse.

A major focus of our corpus-building work is the identification of multiple retranslations of specific works, produced at different moments in time, in different socio-political contexts. For example, the Modern English corpus currently contains six different translations of Plato's Republic, starting with Davis' version in 1849, then Davies and Vaughan in 1852, Jowett in 1871, Shorey in 1937, Grube in 1974 and finally Sachs in $2007 .{ }^{18}$ We have also included Grote's

16 http://genealogiesofknowledge.net/.

17 S. Luz, 'Web-based corpus software' in A. Kruger, K. Wallmach, and J. Munday (eds.), Corpus-based Translation Studies: Research and Applications (London: Bloomsbury, 2011), pp. 124-149; S. Luz and S. Sheehan, 'A graph based abstraction of textual concordances and two renderings for their interactive visualisation', Proceedings of the International Working Conference on Advanced Visual Interfaces, AVI '14 (New York: ACM, 2014), pp. 293-96.

18 Plato, The Works of Plato, A New and Literal Version, Vol. 2, Containing The Republic, Timaeus and Critias, trans. H. Davis (London: Henry G. Bohn, 1849); Plato, The Republic of Plato, Translated into English, trans. J.L. Davies and D.J. Vaughan (Cambridge: MacMillan and co., 1852); Plato, The Dialogues of Plato, in Five Volumes, Translated into English with Analysis and Introductions, trans. B. Jowett (Oxford: Oxford University Press, 1871); Plato, The Republic, Volumes 1 and 2, trans. P. Shorey (Cambridge, MA: Harvard University Press, 1937); Plato, Republic, trans. G.M.A. Grube (Indianapolis: Hackett Publishing Company, 1974); Plato, Republic, trans. J. Sachs (Indianapolis: Hackett Publishing Company, 2007). 
partial translation and commentary on this text, published in $1888 .{ }^{19}$ Similarly, we have so far added nine full or partial retranslations of Thucydides' History of the Peloponnesian War, five interpretations of Herodotus' Histories and four of Aristotle's Politics. ${ }^{20}$ By studying the similarities and differences between these different readings of the foundational works of political and scientific theory, we hope to identify key moments of change in the history of concepts such as 'democracy', 'citizenship', 'rights', 'experiment', 'observation', 'evidence' and 'proof', and thus explore how translations and translators have participated in their transmission and transformation through time and across linguistic and cultural borders.

\section{Searching for a Statesman}

The corpus analysis software developed for this research programme greatly facilitates the identification and investigation of discursive patterns. Not only can concordances be manipulated in various ways to highlight recurrent patterns, but the tools can also produce detailed word frequency information. This numerical data can never give more than a very crude impression of language use in a corpus and so should be treated with a healthy degree of suspicion here, but it should nevertheless be recognised that this information can often serve as an invaluable starting point for more insightful qualitative analysis. Indeed, it is with this quantitative overview that we can productively begin as a means of contextualising our investigation of the concept of statesmanship as it appears in this collection of translated texts. As of 25 June 2018, a search using 'regular expression' syntax for

$$
\text { '(statesman|statesmen)(s|ly|like|ship)?' }
$$

in the GoK Modern English corpus returns a concordance of 1,192 lines. This would suggest the term 'statesman' and its variants 'statesmen', 'statesmanlike', 'statesmanly' and 'statesmanship' (henceforth referred to collectively as 'statesm"') are used with moderate - if certainly not overwhelming frequency in this corpus. 'statesm*' is more common than 'politician(s)' (636

19 George Grote, Plato, and the Other Companions of Sokrates, Volume 2 (London: John Murray, 1888).

20 A full list of the current contents of each of the GoK corpora can be found on our project website: http://genealogiesofknowledge.net/genealogies-knowledge-corpus/ corpus-contents/. 
lines), but significantly less frequent than 'ruler(s)' (2,426 lines) and 'citizen(s) (hip)' (11,575 lines). Most strikingly, however, the dispersion of these occurrences of 'statesm*' is highly unbalanced across the corpus as a whole: 1,06o $(89 \%)$ are found in direct translations of or commentaries on classical Greek texts, leaving only 132 instances of the keyword identified in translations from other languages or from 'non-translations' (i.e. texts originally written in English). This result could of course be a reflection of the far greater size of the 'translations from classical Greek' subcorpus, but, as Table 1 shows, even when the frequency is calculated as a percentage of the total subcorpus word-count, this quantity of hits for 'statesm*' far exceeds that found in any of the other subcorpora by a ratio of well over 7:1. Moreover, we do not find such extreme imbalances in favour of translations from classical Greek for many other keyword searches: for instance, a proportionally much more similar number of lines are returned for the keyword 'citizen(s)(hip)' across a variety of language combinations, including Latin, French, Italian and Spanish, in addition to classical Greek:

TABLE 1 Hits for 'statesm*' and 'citizen*' in the GoK Modern English corpus

\begin{tabular}{lccccc}
\hline \multirow{2}{*}{$\begin{array}{l}\text { Subcorpus source } \\
\text { language }\end{array}$} & $\begin{array}{l}\text { Subcorpus } \\
\text { word-count }\end{array}$ & \multicolumn{2}{l}{ Statesm* } & \multicolumn{3}{c}{ Citizen* } \\
\cline { 3 - 6 } & & Frequency & \% total & Frequency & \% total \\
\hline Classical Greek & $8,843,159$ & 1060 & 0.0120 & 4129 & 0.0467 \\
Latin & $3,838,905$ & 49 & 0.0013 & 2580 & 0.0672 \\
French & $3,064,383$ & 35 & 0.0011 & 1869 & 0.0609 \\
German & $1,662,839$ & 14 & 0.0008 & 233 & 0.0140 \\
Non-translations & $1,465,144$ & 10 & 0.0007 & 2014 & 0.1375 \\
Other & 878,765 & 7 & 0.0008 & 750 & 0.0853 \\
\hline
\end{tabular}

This initial finding is interesting because it would seem to be consistent with Overeem's statement, cited above, that modern ideas about statesmanship have in large part 'been handed down to us from the ancients' and through translations of the works of Greek philosophers Plato and Aristotle in particular. ${ }^{21}$ In fact, as Table 2 illustrates very clearly, when we filter the concordance in order to pick out only those texts in which 'statesm*' occurs ten times or more, we find Plato and Aristotle's names are significantly over-represented in the

21 Overeem, 'Aristotle's Politikos', p. 36. 
list of original authors, with only Grant's (2000) translation of de Tocqueville's Democracy in America, Barham's (1841) version of Cicero's Treatise on the Republic and Havell's (1910) Stories from Thucydides also displaying a comparable number of hits for this keyword ( 25 hits, 17 hits and 10 hits, respectively). ${ }^{22}$ Otherwise, the term barely (if at all) features in translations of works by modern thinkers such as Rousseau (two hits in one text: 53,159 tokens), Hegel (seven hits in five texts: 614,350 tokens), Marx (three hits in three texts: 351,915 tokens), Foucault (one hit in three texts: $35^{8,231}$ tokens), Badiou (zero hits in two texts: 109,998 tokens) or de Sousa Santos (zero hits in three texts: 107,593 tokens).

TABLE 2 Corpus texts in which 'statesm" appears ten times or more

\begin{tabular}{lllllll}
\hline Author & Title & Translator & Date & Word-count & Hits & \% total \\
\hline Plato & Statesman & Skemp & 1992 & 44,258 & 238 & 0.538 \\
Plato & Statesman & Brann et al. & 2012 & 34,343 & 127 & 0.370 \\
Plato & Statesman & Burges & 1850 & 27,245 & 79 & 0.290 \\
Plato & Statesman & Jowett & 1871 & 40,590 & 100 & 0.246 \\
Plato & Statesman & Fowler & 1921 & 26,839 & 60 & 0.224 \\
Plato & Gorgias & Jowett & 1871 & 60,072 & 41 & 0.068 \\
Plato & Meno & Jowett & 1871 & 22,441 & 12 & 0.053 \\
Plato & Gorgias & Cope & 1864 & 69,922 & 32 & 0.046 \\
Plato & Sophist & Jowett & 1871 & 46,216 & 19 & 0.041 \\
Aristotle & Politics & Jowett & 1885 & 147,477 & 55 & 0.037 \\
Grote & Gorgias & - & 1888 & 28,508 & 10 & 0.035 \\
Aristotle & Politics & Rackham & 1932 & 112,843 & 33 & 0.029 \\
Plato & Gorgias & Lamb & 1925 & 39,585 & 11 & 0.028 \\
Cicero & Treatise on the & Barham & 1841 & 70,724 & 17 & 0.024 \\
& Republic & & & & & \\
Plato & Laws & Jowett & 1871 & 241,522 & 39 & 0.016 \\
De Tocqueville & Democracy in & Grant & 2000 & 161,041 & 25 & 0.016 \\
& America & & & & 10 & 0.015 \\
Thucydides & Storiesfrom & Havell & 1910 & 65,208 & & \\
& Thucydides & & & & &
\end{tabular}

22 Cicero, The Political Works of Marcus Tullius Cicero; Comprising his Treatise on the Republic and his Treatise on the Laws, in Two Volumes, Volume 1: The Treatise On the Commonwealth, trans. F. Barham (London: Edmund Spettigue, 1841); A. de Tocqueville, Democracy in America, trans. S. Grant (Indianapolis: Hackett Publishing Company, 200o); H.L. Havell, Stories from Thucydides, Told through the Ages (London: George G. Harrap, 1910). 
TABLE 2 Corpus texts in which 'statesm*' appears ten times or more (cont.)

\begin{tabular}{lllllll} 
Author & Title & Translator & Date & Word-count & Hits & $\%$ total \\
\hline Plato & Republic & Jowett & 1871 & 219,072 & 33 & 0.015 \\
Plato & Laws & Burges & 1852 & 161,320 & 17 & 0.011 \\
Grote & History of Greece & - & 1851 & 203,334 & 19 & 0.009 \\
& $($ vol. 6$)$ & & & & & \\
Grote & History of Greece & - & 1851 & $204,15^{2}$ & 17 & 0.008 \\
& $($ vol. 8$)$ & & & & &
\end{tabular}

Another intriguing feature of the frequency data has to do with the temporal dispersion of this concept within the corpus as a whole. Specifically, if we discount Skemp (1992) and Brann et al.'s (2012) respective translations of Plato's Statesman as outlying anomalies, ${ }^{23}$ a clear pattern emerges in the relative prevalence of this term through time: on the one hand, 'statesm"' appears repeatedly in those translations produced in the second half of the nineteenth century ( $55^{2}$ hits in 99 texts: 7,412,207 tokens) as well as - albeit to a lesser extent - in some versions published in the first half of the twentieth (195 hits in 79 texts: 5,075,476 tokens). Post-1950, on the other hand, the corpus browser returns just 63 lines for the keyword search, spread across 118 texts $(6,037,209$ tokens). ${ }^{24}$ As we will discuss in more detail below, this diachronic imbalance is curious given that the GoK Modern English corpus contains several retranslations of classical texts such as Aristotle's Politics or Plato's Dialogues published within the last seventy years, i.e. texts which in earlier English-language

23 Plato, Statesman, trans. J.B. Skemp, rev. M. Ostwald (Indianapolis: Hackett Publishing Company, 1992); Plato, Statesman, trans. E. Brann, P. Kalkavage and E. Salem (Indianapolis: Focus, 2012). As Table 2 shows, Skemp and Brann et al.'s translations of Plato's Statesman contain 238 and 127 hits for 'statesm*' respectively. This can only be explained by the extent to which the association between this dialogue (entitled Politikos in the Greek) and the term 'statesman' have become 'hard-wired' into modern discussions of Plato's philosophy. It would, in other words, be difficult for a new translation of the text known as Statesman in the receiving context to avoid using the word 'statesman' within the main body of its text without causing considerable confusion amongst readers.

24 Interestingly, this decline in the use of 'statesm*' over the past 150 years can also be seen in the results of a Google NGram visualisation generated for these terms (https://books. google.com/ngrams). According to this dataset too, 'statesman' and 'statesmanship' appear to have enjoyed a period of greater prominence in books published between 1860 and 1900 , while before and after this date this search item is found with strikingly less frequency. 
interpretations presented the keyword 'statesm"' very prominently (see Table 2).

In order to investigate the features of this ideal of the statesman inherited from the classical world, we must now turn to a qualitative inspection of the individual concordance lines extracted from this subcorpus of translations from ancient Greek. This analysis examines not only instances of 'statesm"' located in the translated target texts themselves, but also concordance lines retrieved from the translators' introductions and footnotes, conceptualised as prominent 'paratextual' components in the construction of each translation product holding a significant shaping influence over the re-mediation and reception of the source text in the target culture. ${ }^{25}$ Through this analysis, we find strong parallels with the modern picture of statesmanship outlined by Clarke, Symonds and the $O E D$, and summarised in the introduction above. To begin with, as in Clarke's and Symonds' essays, the statesman is first and foremost depicted in these translated texts as a political leader, one who is actively engaged in 'ruling' or 'controlling' the state:

[1] Obviously, then, we must try to define the way in which the statesman controls the state. ${ }^{26}$

[2] For being the most powerful man of his time, and the leading Athenian statesman, he opposed the Lacedaemonians in everything, and would have no concessions, but ever urged the Athenians on to war. ${ }^{27}$

[3] the statesman, the man who controls or is competent to control, singly or with colleagues, the administration of the commonwealth. ${ }^{28}$

[4] Let us go back once again to the parallel cases with which we have constantly to compare the ruler who really is a statesman. ${ }^{29}$

In this role, we find that he is occupied largely with legislation and the management of competing interests in society:

25 On the role of paratextual elements such as introductions and footnotes in shaping the reception of a translation, see K. Batchelor, Translation and Paratexts: Paratexts and translation theory (London: Routledge, 2018).

26 Plato, Statesman, trans. Skemp, p. 33.

27 Thucydides, History of the Peloponnesian War, trans. R. Crawley (London: J.M. Dent and Sons, 1874), p. 82.

28 Aristotle, Politics, trans. H. Rackham (Cambridge, MA: Harvard University Press, 1932), p. 199 .

29 Plato, Statesman, trans. J.B. Skemp (London: Routledge, 1952), p. 203. 
[5] the good lawgiver and the true statesman must be acquainted with both the form of constitution that is the highest absolutely and that which is best under assumed conditions. ${ }^{30}$

[6] Plato's legislators or guardians are to be fitted for their work of statesmen by the study of the five mathematical sciences. ${ }^{31}$

[7] But if any legislator or state proceeds beyond these, by leading either riches to honours, or by placing by means of honours in the foremost rank any of the things in the rear, he will do a deed neither holy nor statesman-like. ${ }^{32}$

[8] True statesmanship is the knowledge of combining courageous and moderate natures into one all-encompassing weave. This artful act of weaving produces unanimity, friendship, and the happiness appropriate to a city. ${ }^{33}$

But beyond these more practical tasks, he also adopts a strongly paternalistic approach to government and is framed by many of the corpus texts as a teacher of men, someone who instructs citizens in ways that might make them 'as good as possible':

[9] These are the principles in which the statesman should train his citizens. ${ }^{34}$

[10] Or can it be, then, that you will let us see you concerning yourself with anything else in your management of the city's affairs than making us, the citizens, as good as possible? Have we not more than once already admitted that this is what the statesman ought to do? ${ }^{35}$

$30 \quad$ Aristotle, Politics, trans. Rackham, p. 279.

31 B. Jowett, 'Introduction to the Republic' in Plato, The Dialogues of Plato, in Five Volumes, Translated into English with Analysis and Introductions, Vol. 3, trans. B. Jowett (Oxford: Oxford University Press, 1871), p. cxcv.

32 Plato, 'Laws' in The Works of Plato, A New and Literal Version, Vol. 5, Containing the Laws, trans. George Burges (London: Henry G. Bohn, 1852), pp. 111-12.

33 Plato, Statesman, trans. Brann et al., p. 12.

34 B. Jowett, 'Introduction' in Aristotle, The Politics of Aristotle Translated into English with Introduction, Marginal Analysis, Essays, Notes and Indices, Vol. 1, trans. B. Jowett (Oxford: Clarendon Press, 1885), p. cxxxiii.

35 Plato, Gorgias, trans. W.R.M. Lamb (Cambridge, MA: Harvard University Press, 1925), p. 493 . 
[11] The proper and paramount function of statesmen (we find it eloquently proclaimed) is to serve as spiritual teachers in the community. ${ }^{36}$

[12] As to Nicias and Thucydides, nearly every one agrees that they were not merely men of birth and character, but also statesmen, and that they ruled the state with paternal care. ${ }^{37}$

Under his guidance, a whole population may thus act in a 'statesmanlike' manner, as the Athenians and Lacedaemonians are said to do in Examples 13 and 14 below, and there is some suggestion that any citizen living in a free state might be able to learn something of the 'art of statesmanship':

[13] the Athenians appear both in private and public to have behaved towards the past disasters in the most completely honorable and statesmanlike manner of any people in history. ${ }^{38}$

[14] Do we deserve, then, Lacedaemonians, considering the public spirit and the statesmanship we then displayed, to be objects of such intense jealousy to Greece, if that jealousy is founded on the dominion we hold? 39

[15] For every citizen in a free state should learn how to become a statesman by being first a simple citizen, just as he would learn the duties of a general by being under the orders of a general. ${ }^{40}$

[16] Socrates said: If in the minor arts great achievement is impossible without competent masters, surely it is absurd to imagine that the art of statesmanship, the greatest of all accomplishments, comes to a man of its own accord. ${ }^{41}$

36 G. Grote, 'Gorgias' in Plato and the Other Companions of Sokrates, Volume 2 (London: John Murray, 1888), p. 362 .

37 Aristotle, On The Athenian Constitution, With Introduction and Notes, trans. F. Kenyon (London: G. Bell and Sons, 1891), p. 54.

38 Aristotle, The Athenian Constitution, trans. H. Rackham (Cambridge, MA: Harvard University Press, 1935), p. 113 .

39 Thucydides, Speeches from Thucydides, Translated into English for the Use of Students, with an Introduction and Notes, 2nd edition, trans. H.M. Wilkins (London: Longmans, Green and Co., 1873), p. 28.

40 Jowett, 'Introduction' in Aristotle, The Politics of Aristotle, trans. Jowett, p. liv.

41 Xenophon, 'Memorabilia' in Xenophon in Seven Volumes, Volume 4: Memorabilia and Oeconomicus, trans. E.C. Marchant (Cambridge, MA: Harvard University Press, 1923), p. 283 . 
However, the 'true statesman' himself is emphatically not an 'ordinary man'; in fact, the corpus texts often present the two labels as mutually exclusive (e.g. Examples 17 and 18). Some translations of Plato's Meno (Example 19) even go so far as to suggest that the statesman's inspiration and virtue is derived from the gods and therefore that real statesmanship cannot possibly be attained by most citizens, even if they receive tutelage:

[17] No ordinary man can discern the beginning of evil, but only the true statesman. ${ }^{42}$

[18] to discern a growing evil at the commencement is not any ordinary person's work but needs a statesman. ${ }^{43}$

[19] Then we shall be right in calling those divine of whom we spoke just now as soothsayers and prophets and all of the poetic turn; and especially we can say of the statesmen that they are divine and enraptured, as being inspired and possessed of God when they succeed in speaking many great things. ${ }^{44}$

[20] good practical statesmen receive right opinion by inspiration from the Gods. ${ }^{45}$

Indeed, as in Clarke's essay, ${ }^{46}$ the statesman's 'right to bear rule' and 'have the advantage over the rest' is primarily attributed to his extraordinary 'knowledge and skill to form plans [...] and the energy and vigour to carry them into execution' (Example 21). It is, in other words, the statesman's superior wisdom, intelligence and expertise in political matters that justifies his influence and power in society. In some translations of Aristotle's Politics, statesmen and their abilities are consequently framed as an essential component of a fair and equitable society (Example 24):

[21] then Callicles finally pronounces that the strength and superiority that he really means lies in a union of the highest qualities of the statesman, the knowledge and skill to form plans (for the public good and his own) or to frame a policy, and the energy and vigour to carry them into execution. "These are the men that have a right

\footnotetext{
42 Aristotle, The Politics of Aristotle, trans. Jowett, p. 164.

43 Aristotle, Politics, trans. Rackham, p. 423.

44 Plato, Meno, trans. W.R.M. Lamb (Cambridge, MA: Harvard University Press, 1924), p. 369.

45 Grote, 'Menon' in Plato and the Other Companions of Sokrates, p. 241n.

46 Clarke, 'Wanted, A Statesman!', p. 645.
} 
to bear rule, and justice consists in this, that these should have the advantage over the rest $[\ldots]^{147}$

[22] To this we answer that the good ruler is a good and wise man, and that he who would be a statesman must be a wise man. ${ }^{48}$

[23] A true statesman ought to prove the wisdom of his policy, not by intimidating opposition, but by meeting it on equal terms. ${ }^{49}$

[24] If the presence of all these elements, and their fair and equitable organization, is necessary to states, then there must also be persons who have the ability of statesmen. ${ }^{50}$

Finally, the statesman is also presented as a paragon of virtue, honour and patriotism, wholly occupied with the well-being of his state:

[25] Others think the life of the statesman the best on the ground that virtuous activity is happiness. ${ }^{51}$

[26] You voted for war; yet you are angry with me, a man who hold myself second to none in judging of the course to be pursued, and in clearly stating my views: a lover, too, of my country, and proof against corruption. Qualities all indispensable in a statesman. ${ }^{52}$

[27] He therefore abstained from food till he died, considering that even the death of a statesman should be of service to the state, and the ending of his life not void of effect, but recognized as a virtuous deed. ${ }^{53}$

[28] Men of refinement with a practical turn prefer honour; for I suppose we may say that honour is the aim of the statesman's life.$^{54}$

The label 'statesman' is therefore unambiguously positive in its connotations, a clear mark of 'admiration and respect' (Example 29), sought after by many but

47 E.M. Cope, 'Introduction' in Plato, Plato's Gorgias, literally translated, with an introductory essay, containing a summary of the argument, trans. E.M. Cope (Cambridge: Deighton, Bell and co., 1864), p. li.

48 Aristotle, The Politics of Aristotle, trans. Jowett, p. 73.

49 Thucydides, Speeches from Thucydides, trans. Wilkins, p. 111.

50 Aristotle, The Politics of Aristotle, trans. Jowett, p. 115.

$51 \quad$ Jowett, 'Introduction' in Aristotle, The Politics of Aristotle, trans. Jowett, p. cxiii.

$5^{2}$ Thucydides, Speeches from Thucydides, trans. Wilkins, p. 79.

53 Plutarch, 'Lycurgus', in Plutarch's Lives in Eleven Volumes, Volume 1: Theseus and Romulus, Lycurgus and Numa, Solon and Publicola, trans. Bernadotte Perrin (Cambridge, MA: Harvard University Press, 1914), p. 295.

54 Aristotle, The Nicomachean Ethics of Aristotle, trans. F.H. Peters (London: Kegan Paul and Co., 1881), p. 7 . 
accorded to very few individuals in any generation. Pericles' name stands out as the most commonly cited example of such a man but the number of other individuals worthy of the title is limited to single figures within the 8.8 million words of the subcorpus as a whole:

[29] Their claim to admiration and respect as statesmen must be estimated by the moral progress made by the citizens whilst under their care. ${ }^{55}$

[30] Nicias, while still happy and honoured, wished to secure his good fortune, to obtain a present release from trouble for himself and his countrymen, and hand down to posterity a name as an eversuccessful statesman. ${ }^{56}$

[31] At last Pericles the son of Xanthippus, who was the first man of his day at Athens, and the greatest orator and statesman, came forward and advised as follows: 57

[32] The best statesmen at Athens, after those of early times, seem to have been Nicias, Thucydides, and Theramenes. 58

[33] the Athenian statesmen of a former generation, who showed no weakness and made no mistakes, such as Miltiades, Themistocles, Pericles, are his favourites. ${ }^{59}$

[34] He also admired and emulated, above all other statesmen, Lycurgus the Lacedaemonian. ${ }^{60}$

To sum up, the vision of the statesman presented in these modern-era translations of these ancient texts would seem to accord very closely with the images of statesmanship presented in essays such as those by Clarke and Symonds, and in reference works such as the Oxford English Dictionary. On the face of it, the Greek philosophers and historians cited above too saw the statesman as a strongly idealised leader and moral teacher, distinguished from the masses by his superior political acumen, expertise and experience. They too used the

55 Cope, 'Introduction' in Plato, Plato's Gorgias, trans. Cope, p. lxx.

56 Thucydides, History, trans. Crawley, p. 345.

57 Thucydides, Thucydides, Translated into English, with Introduction, Marginal Analysis, Notes and Indices, trans. B. Jowett (Oxford: Clarendon Press, 1881), p. 88.

$5^{8}$ Aristotle, On The Athenian Constitution, trans. Kenyon, pp. 53-54.

59 Plato, 'Gorgias', in The Dialogues of Plato, in Five Volumes, Translated into English with Analysis and Introductions, Vol. II, trans. B. Jowett (Oxford: Oxford University Press, 1871), p. 273 .

6o Plutarch, Plutarch's Themistocles and Aristides, Newly Translated, with Introduction and Notes, trans. B. Perrin (New York: Charles Scribner's Sons, 1901), p. 125. 
label as a decisively positive accolade and, although statesmanship is discussed mainly in abstract theoretical terms, it would seem that these writers did apply the term to an elite few real historical individuals. Yet, as we will see in the next section, the ostensibly perfect continuity of this concept across the millennia and the seemingly transparent nature of the language barrier in this process of knowledge transmission does not hold up to scrutiny when we begin to dig further into the part translation has played in the development and dissemination of these ideas.

\section{4}

\section{Unstable Foundations}

First, we must highlight the deep ambiguity of meaning associated with the Greek term $\pi 0 \lambda i \tau i x o$ s, that is, the term which is most commonly referenced as the direct equivalent of the English word 'statesman'.61 Primarily categorised as an adjective, $\pi 0 \lambda i \tau$ ixós is derived from the noun $\pi \circ \lambda i \tau \eta s$, which itself is

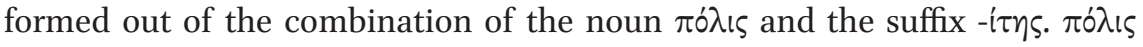
is the term used to refer to a 'city-state', both in the sense of a geographically bounded region or settlement, and as a group of people that live together in

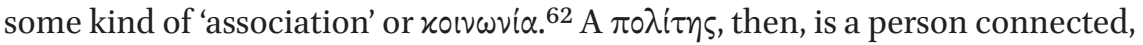
concerned or occupied with this $\pi \dot{\lambda} \lambda$ l६; they are a recognised member of this community. ${ }^{63}$ As such, the noun is generally translated into English as 'citizen' as, for example, when Jowett (1885) interprets Aristotle's statement in the Politics that

in some democracies a man is a citizen [ $\pi \circ \lambda i \tau \eta \varsigma]$ though his mother only be a citizen $[\pi \circ \lambda i \tau \iota \varsigma] .{ }^{64}$

As an adjective produced through the addition of the associative suffix -ixós, $\pi 0 \lambda$ เाเкós can thus be understood most simply as meaning 'of, for, or relating

61 As an example of the ways in which a relationship of direct equivalence is often established between the Greek 'politikos' and the English 'statesman', see M.L. Gill, 'Method and Metaphysics in Plato's Sophist and Statesman', Stanford Encyclopedia of Philosophy (2015), https://plato.stanford.edu/entries/plato-sophstate/ (accessed August og, 2018). In Section 3.1 of this essay, for instance, she writes "[t]he word "statesman" in Greek (politikos) is cognate with the word "city" (polis).'

62 M.H. Hansen, Polis: An introduction to the ancient Greek city-state (Oxford: Oxford University Press, 2006), p. 57 .

63 H.W. Smyth, A Greek Grammar for Colleges (New York: American Book Company, 1920), p. 843 .

64 Aristotle, The Politics of Aristotle, trans. Jowett, p. 76. 
to citizens' or 'consisting of citizens' ${ }^{65}$ Yet, Greek-English dictionaries also suggest 'civic' and 'civil', as well as 'belonging to the state or its administration'.66 It is in this last definition that we can understand the logic of $\pi 0 \lambda \imath \tau i x o ́ \varsigma$ as the etymon for the modern English adjective 'political' and its cognates, and it is not uncommon to find $\pi 0 \lambda i \tau i x o ́ s$ translated by 'political' directly. Shorey, for instance, renders a line from Plato's Republic as follows:

For the modes of music are never disturbed without unsettling of the most fundamental political and social conventions $[\pi \circ \lambda ı \tau \iota \kappa \hat{\omega} \nu \nu o ́ \mu \omega \nu] .{ }^{67}$

Similarly, Sachs follows a long line of translators in settling for 'political associ-

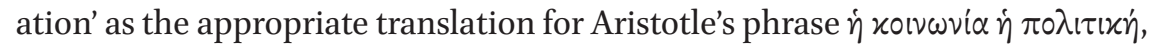
explaining in a footnote that by 'political' he means 'of or pertaining to a city (polis). ${ }^{68}$

To complicate matters, however, $\pi 0 \lambda$ เ $\tau$ ixós is frequently used substantively,

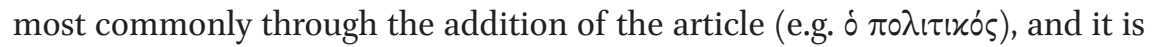
principally as a noun that $\pi \circ \lambda ı \tau i x o$ s has been rendered by some translators as 'statesman'.69 This is certainly the case in many of the examples already cited above: the Greek text corresponding to the definition of the statesman provided in Example 3, for instance, uses the word $\pi 0 \lambda \iota \tau$ xós in this way:

[3] the statesman [ $\dot{0} \pi 0 \lambda i \tau i x o ́ s]$, the man who controls or is competent to control, singly or with colleagues, the administration of the commonwealth. ${ }^{70}$

Yet, as this section has aimed to demonstrate and as Overeem has also discussed, ${ }^{71}$ this is by no means the only possible interpretation of this word: indeed, alternative translations of such passages - and especially those

65 H.G. Liddell and R. Scott, A Greek-English Lexicon, revised and augmented throughout by Sir Henry Stuart Jones with the assistance of Roderick McKenzie (Oxford: Clarendon Press, 1940), p. 163 .

66 H.G. Liddell and R. Scott, A Greek-English Lexicon, p. 163.

67 Plato, The Republic, Volumes 1 and 2, trans. P. Shorey (Cambridge, MA: Harvard University Press, 1937), p. 424.

68 Aristotle, Politics, trans. J. Sachs (Indianapolis: Hackett Publishing Company, 2012), p. 1.

69 To be precise, ancient Greek authors often use the article in a manner that dispenses entirely with the noun which an adjective such as politikos is meant to describe, leaving readers to infer this substantive from the context (Smyth, A Greek Grammar for Colleges, p. 1021).

70 Aristotle, Politics, trans. Rackham, p. 199.

71 Overeem, 'Aristotle's Politikos', p. 36. 
published from around $195^{\circ}$ onwards - frequently provide a strikingly different rendering. Take for example the following extract from Sachs' (2012) recent retranslation of precisely the same passage from the Politics:

[3A] one involved in political affairs [o $\pi 0 \lambda ı \tau i x o ́ s]$ and having authority, or capable of authority, either on his own or along with others, over the management of common concerns. ${ }^{72}$

Here, Aristotle no longer appears to be suggesting it is the 'statesman' who controls the administration of the commonwealth, but merely those 'involved in political affairs'. Similarly, while Jowett (1885) and Rackham (1932) both translate $\tau \dot{o} v \dot{\alpha} \lambda \eta \theta \hat{\omega} \varsigma \pi 0 \lambda \imath \tau$ ióv as 'the true statesman' in each of their respective versions of the segment cited in Example 5, Sachs (2012) again chooses to interpret this same phrase as 'anyone who is a student of politics in the true sense', thus offering a vastly more inclusive interpretation of who Aristotle is suggesting might be involved in politics as a practical and theoretical activity:

[5] the good lawgiver and the true statesman must be acquainted with both the form of constitution that is the highest absolutely and that which is best under assumed conditions. ${ }^{73}$

[5A the true legislator and statesman ought to be acquainted, not only with (1) that which is best in the abstract, but also with (2) that which is best relatively to circumstances. ${ }^{74}$

[5B] a good lawgiver and anyone who is a student of politics in the true sense ought not either to overlook the form [of government] that is most effective simply or the best form that can come from the underlying conditions. ${ }^{75}$

My argument here does not seek to assess whether any of these translations is uncontrovertibly more 'correct' or 'accurate' than the others. Rather the point is that the relation of equivalence between ' $\pi 0 \lambda$ iाixós' and 'statesman' is by no means as clear cut as it is often presented. A wide variety of connotations are bound up in the source-language term, opening up a broad interpretative space within which the potential translator must chart his or her own course.

72 Aristotle, Politics, trans. Sachs, p. 74.

73 Aristotle, Politics, trans. Rackham, p. 279.

74 Aristotle, Politics, trans. Jowett, pp. 107-108.

75 Aristotle, Politics, trans. Sachs, p. 73. 


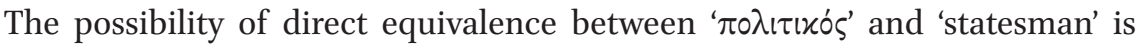
further disrupted when we investigate in additional detail the relationships between source and target texts, and find that a plethora of different terms have been combined and conflated in and through their translation as 'statesman', 'statesmen' and/or 'statesmanship'. While $\pi 0 \lambda$ ı $\tau$ ixós is certainly the most common Greek word from which many of the instances of 'statesm*' identified have been derived (it features in the source text for 14 of the 34 examples cited above), it is not the only one. When, for instance, Crawley writes in his 1874 translation of Thucydides' History of the Peloponnesian War:

[1] For being the most powerful man of his time, and the leading Athenian statesman, he opposed the Lacedaemonians in everything, and would have no concessions, but ever urged the Athenians on to war, 76

there is no mention of Pericles, the historical figure who Thucydides is describ-

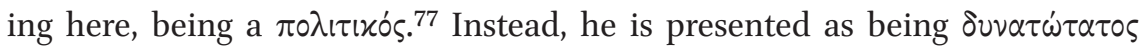

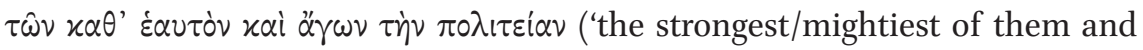
[the one] leading the political realm'). In other words, the nineteenth-century translator has interpreted this quality of being $\delta v v \alpha \tau \omega$ ' $\alpha \tau$ ( est') and Pericles' leading influence ( $\alpha \gamma \gamma \omega \nu)$ in Athenian society as equivalent to his modern understanding of statesmanship and imposed the connotations connected with this target-culture concept onto Thucydides' text, despite the fact that no single word in the Greek can be said to match like-for-like onto the modern English rendering. Similarly, when Kenyon has Aristotle state in the Athenian Constitution that:

[32] The best statesmen at Athens, after those of early times, seem to have been Nicias, Thucydides, and Theramenes. ${ }^{78}$

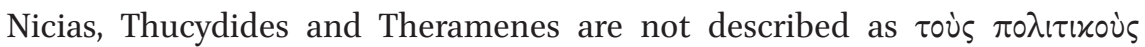

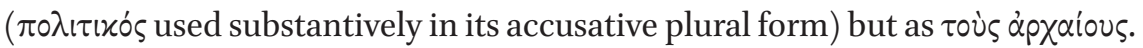

76 Thucydides, History, trans. Crawley, p. 82.

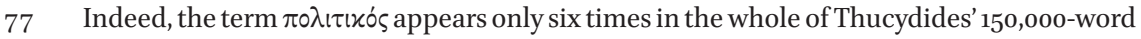
History.

78 Aristotle, On the Athenian Constitution, trans. Kenyon, pp. 53-54. 
As Hansen notes, this alternative term is derived from the word $\dot{\alpha} x \chi \dot{\eta}$ and is consequently used

to refer to officials appointed by election or sortition for a shorter period, mostly a year, and entrusted with the day-to-day administration of the polis and carrying into effect the decisions of the Assembly, the Council and the courts. ${ }^{79}$

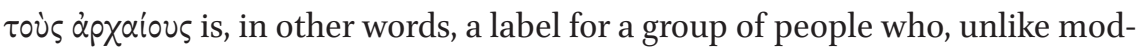
ern conceptions of statesmen, do not necessarily possess particular expertise in political affairs or exceptional moral integrity as leaders. Indeed, Hansen's gloss would suggest 'magistrates' or even 'civil servants' as a possible translation of this term, that is, almost apolitical characters who carry out the will of others, rather than themselves propose new policy or legislation. To return to Clarke's nautical analogy, an $\alpha \rho p y$ ' would not necessarily be one to 'put his hand on the rudder' of the state, functioning more like the metaphorical rudder itself than the steersman.

The additional examples listed below illustrate how several other sourcelanguage terms have been conflated in and through their translation as 'statesman(ship)', particularly it would seem in those English-language versions of Greek historical texts (e.g. Thucydides and Polybius) published in the second half of the nineteenth century and the beginning of the twentieth (a finding that accords with the quantitative analysis of the concept's temporal dispersion presented above). In Example 23, it is the Greek word for an ordinary member of the $\pi \dot{\lambda} \lambda ı$ - a $\pi \circ \lambda i$ in (more commonly translated by 'citizen') - which is replaced by 'statesman' in another English version of Thucydides' History (by Wilkins in 1873), while in Example 35 we find a whole clause con-

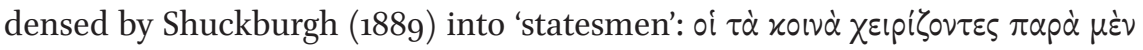

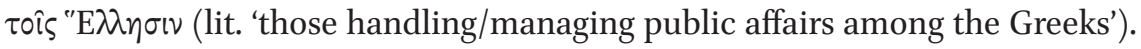

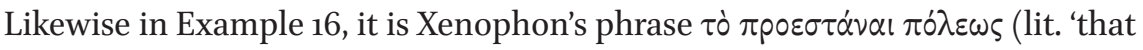
[art] of those acting as leaders/protectors of the city') which becomes 'the art of statesmanship' in Marchant's (1923) rendering of the Memorabilia:

[23] A true statesman [ $\pi 0 \lambda i \tau \eta \nu]$ ought to prove the wisdom of his policy, not by intimidating opposition, but by meeting it on equal terms. ${ }^{80}$

\footnotetext{
79 Hansen, Polis, p. 171.

$80 \quad$ Thucydides, Speeches from Thucydides, trans. Wilkins, p. 111.
} 
[35] This is the reason why, apart from anything else, Greek statesmen

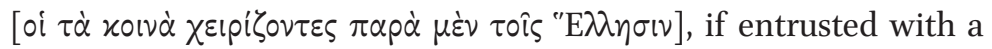
single talent, though protected by ten checking-clerks, as many seals, and twice as many witnesses, yet cannot be induced to keep faith. ${ }^{81}$

[16] Socrates said: If in the minor arts great achievement is impossible without competent masters, surely it is absurd to imagine that

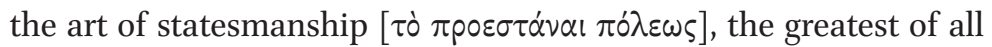
accomplishments, comes to a man of its own accord. ${ }^{82}$

Once again, my argument here does not seek to imply simply that such translations are wholly and fundamentally inaccurate. Rather, the point is that, while on the basis of their English versions, these classical Greek texts appear to contain a strong, coherent discourse of statesmanship, apparently pervasive throughout the classical canon, comparison with the original-language materials gives quite a different impression. A multiplicity of Greek terms and phrases - each with their own unique set of connotations in the source language and culture - have been combined and conflated as these texts have been transmitted across languages and over the centuries, and specific acts of translation are thus shown to have been crucially involved in the construction and dissemination of modern ideas regarding this ancient political ideal.

\section{$6 \quad$ Ideological Implications, Possible Explanations}

This conclusion is all the more interesting and important when we consider the ideological implications of these word choices and begin to offer possible explanations for them. Given the unequivocally positive and extraordinary attributes accorded to the statesman in the receiving culture, it can be argued that re-framing the leading participants in classical Greek politics and history as 'statesmen' (rather than as 'politicians' or even 'politically engaged citizens' 83 ) has a number of significant effects: most notably, it may suggest a rigid, natural hierarchy between these rulers and their subjects, not simply on the basis of power wielded but more fundamentally in terms of morality, rationality and political acumen. For instance, if we return to Example 24, Jowett's

\footnotetext{
81 Polybius, The Histories of Polybius, Translated from the Text of F. Hultsch, in Two Volumes, Vol. I, trans. E.S. Shuckburgh (London: Macmillan and Co., 1889), p. 506.

82 Xenophon, 'Memorabilia', trans. Marchant, p. 283.

83 Overeem, 'Aristotle's Politikos', p. 36.
} 


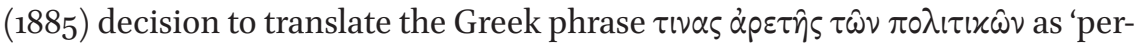
sons who have the ability of statesmen' paints a dramatically different picture to that portrayed by Rackham (1932) and Sachs' (2012) later renderings, both in terms of who might be involved in ensuring the 'fair and equitable organisation' of Aristotle's ideal society and in terms of the extent to which these individuals might be superior to their peers in political ability and/or virtue: ${ }^{84}$

[24] If the presence of all these elements, and their fair and equitable organization, is necessary to states, then there must also be persons who have the ability of statesmen. ${ }^{85}$

[24A] If therefore it is proper for the states to have these functions performed, and well and justly performed, it is necessary for there also to be some men possessing virtue in the form of political excellence. ${ }^{86}$

[24B] So if these things need to be done in cities, and be done in a beautiful and just manner, it is necessary for there to be some people who share the virtue of citizens. ${ }^{87}$

While Jowett's version suggests only statesmen are sufficiently qualified to occupy this role and that statesmen are by definition more able to govern than others, the later translations - and Sachs' in particular - offer the possibility that Aristotle believed quite the opposite, namely, that all virtuous citizens should share the responsibility of state management. The former thus puts forward a distinctly aristocratic reading of Aristotelian philosophy, a reading that the latter two strongly contest.

84 It should be noted that there is some debate surrounding the precise wording of this section (1291b) of the source text and that the three translators are not in fact basing their versions on the same edition of the Greek. While the Bekker edition on which Jowett relied has $\tau i v \alpha \varsigma \dot{\alpha} \rho \tau \hat{\jmath} \varsigma \tau \hat{\omega} \nu \pi 0 \lambda \iota \tau i x \hat{\omega} \nu$, the Loeb edition which Rackham used proposes

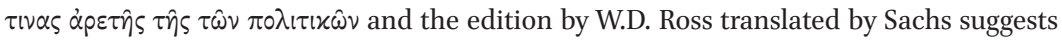
$\tau \imath \nu \alpha \varsigma \dot{\alpha} \varepsilon \tau \hat{\jmath} \varsigma \tau \hat{\omega} \nu \pi 0 \lambda \imath \tau \hat{\omega} v$. These variations in the Greek would therefore explain at least partially the divergence of interpretations between Jowett and Sachs, but not the differences between Jowett's and Rackham's translations (the added ' $\tau \hat{\eta} \varsigma$ ' in the Loeb version being largely inconsequential in this context). Moreover, none of the translators (Sachs included) acknowledge the discrepancies between the manuscripts at this point in their translations and the very fact of Sachs having perhaps here preferred a different version of the source text, while Jowett and Rackham prefer others, itself represents an important decision in shaping the reception of Aristotle's thought in English.

85 Aristotle, Politics, trans. Jowett, p. 115.

86 Aristotle, Politics, trans. Rackham, pp. 297-298.

87 Aristotle, Politics, trans. Sachs, p. 110. 
In light of these observations, it is argued that the marked tendency among late nineteenth- and early twentieth-century translators such as Jowett to

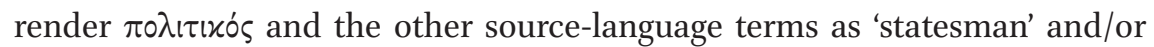
'statesmanship' might be explained, at least in part, with reference to historical anxieties within this target context regarding the viability of democratic rule. In late-Victorian Britain especially, and despite the series of electoral reforms that from 1831 onwards had bestowed suffrage on a successively greater proportion of the population, many prominent members of the ruling classes remained deeply sceptical as to the extent to which the 'working man' was sufficiently capable, reasonable and morally scrupulous to be entrusted with state affairs. As Wright has discussed, even pro-democratic intellectuals such as John Stuart Mill refused to allow that the unpropertied and undereducated masses were 'responsible' enough to become actively involved in government, fearing their decisions were all too likely to be motivated by individual self-interest, rather than reason and the general good. ${ }^{88}$ Moreover, in his Considerations on Representative Government, Mill also highlighted the general public's lack of 'special training and knowledge' in political matters and consequently advocated the institution of a 'Chamber of Statesmen' as the best means of moderating and regulating the democratic ascendancy. 89 Through the interventions of these 'natural leaders', he wrote, pre-selected on merit and experience, 'the power of holding the people back would be vested in those most competent, and [those] who would then be most inclined to lead them forward in any right course' ${ }^{90}$ In other words, the desire to maintain elite control over the reins of government by empowering skilled, practiced and incorruptible 'statesmen' as unelected leaders occupied a central position in Mill's vision of the ideal British democracy.

Investigation into the biographies of the nineteenth-century translators included in the corpus reveals that many of these individuals too - themselves members of the ruling classes - held comparable views. Most notably, and as discussed by Jones, ${ }^{91}$ Benjamin Jowett was similarly committed to the idea that democracy could work as a system of government only if controlled by a higher political authority: convinced of the 'unfitness of the lower classes

88 D.G. Wright, Democracy and Reform 1815-1885 (London: Longman, 1970), p. 61.

89 J.S. Mill, Considerations on Representative Government (London: Parker, Son and Bourn, 1861), pp. 236-7.

$90 \quad$ Mill, Considerations on Representative Government, p. 237.

91 H. Jones, 'Jowett's Thucydides: A corpus-based analysis of translation as political intervention' (forthcoming). 
to govern themselves, ${ }^{92}$ he saw it as his duty in his role as Regius Professor of Greek and Master of Balliol College, Oxford, to train the future leaders of the people as 'Platonic guardians for Britain and its Empire'.93 As is particularly clear in the translator's introduction to his version of Plato's Gorgias (1871), it was only these rigorously educated elites who, in Jowett's opinion, could possibly protect the unity of the nation against the individualistic, destabilising pressures of popular political participation: 'the many', he believed, 'cannot exist without the few'.94

Translation practices in this context, then, may well have reflected and responded to this societal unease. By interpreting these classical texts in ways that highlight the role of 'statesmen' in ancient Greek history and political thought, it is possible that translators such as Jowett, Burges, Cope, Wilkins and others sought to emphasise the importance of effective, knowledgeable, morally guided leadership within democratic states, and hence legitimise the continued dominance of a privileged elite at the top of the British social hierarchy. The extent to which this constituted a deliberate, conscious strategy is of course very difficult to prove at this historical distance, and it is certainly likely that other factors - such as questions of style and target audience - were also at play. Yet, given the strength of the patterns observed and presented in this paper, it is in my view not inconceivable that many of the individuals involved were at least aware of the potential implications of lending the classics' authority in this way to political ideas already circulating in society.

What is perhaps more certain is that in more recent times - during a period now characterised by the 'hegemony of the democratic ideal'95 - translators have become interested in exploring other dimensions of these classical texts. As exemplified in the translations of Sachs, Grube, Rhodes, Irwin, Lattimore, Arieti and Barrus, ${ }^{96}$ these new re-readings frequently offer an understanding of the Greek world which diverges significantly from that of earlier generations,

92 B. Jowett, cited in E. Abbott and L. Campbell, The Life and Letters of Benjamin Jowett, M. A., Master of Balliol College, Oxford, Volume 2 (London: J. Murray, 1897), p. 210.

93 C. Stray, Classics Transformed: Schools, Universities and Society in England, 1830-1960 (Oxford: Clarendon Press, 1998), p. 122.

94 B. Jowett, 'Introduction to the Gorgias', in Plato, Gorgias, trans. Jowett, p. 311.

95 R. Hanson, 'Democracy' in T. Ball, J. Farr and R. Hanson (eds.), Political Innovation and Conceptual Change (Cambridge: Cambridge University Press, 1989), p. 68.

96 See Aristotle, The Athenian Constitution, trans. P.J. Rhodes (London: Penguin, 1984); Aristotle, Nicomachean Ethics, trans. T. Irwin (Indianapolis: Hackett Publishing Company, 200o); Aristotle, Politics, trans. Sachs; Plato, Republic, trans. Grube; Plato, Republic, trans. Sachs; Plato, 'Gorgias' in Plato: Gorgias and Aristotle: Rhetoric, trans. J. Sachs (Indianapolis: Hackett Publishing Company, 2009); Thucydides, The Peloponnesian War, trans. S. Lattimore (Indianapolis: Hackett Publishing Company, 1998). 
thus foregrounding the wide variety of possible interpretations contained within these ancient works. This too could have to do with questions of style and target audience: Sachs' aim as far as his translations are concerned, for example, is to 'bring the reading experience as close to the original as possible', while Jowett's texts are widely acknowledged as freer interpretations of their sources, made to transform these ancient works into 'English classics. ${ }^{97}$ Nevertheless, the analysis presented in this paper would suggest that changes in the political landscape over the past 150 years should additionally be considered an important contributing factor.

\section{Summary and Conclusions}

To conclude, this paper has sought to demonstrate that the discourse of statesmanship presented in translations from ancient Greek is just as much the product of the receiving culture as it is inherited from the classical world. Through comparative analyses of the source- and target-language terminology used with reference to this concept across a large corpus of translated texts, translation and translators have been shown to have played a central role in shaping modern understandings of ancient political thought. I have suggested that this could have been particularly the case in Britain in the late nineteenth and early twentieth centuries, when translators as members of the ruling classes appear to have attempted to shore up their position in society against the democratisation of political power through their word choices. Since the 1950s, however, translators seem to be contesting the aristocratic connotations of statesmanship in their work and to be seeking out other readings which explore alternative dimensions of the source texts and language.

The methodological approach adopted in this study does of course have its shortcomings: most notably, in attempting to highlight the pervasiveness of the discourse of statesmanship across this corpus of translated classical texts, I have tended to overlook more subtle differences both in the ways in which different source authors use language and in the ways in which different translators have interpreted them. Consequently, future research should seek to pick apart the nuanced variety of uses of these terms across this and other collections of (translated) political discourse. It would be particularly productive, for example, to examine the differences in the use of the term 'statesman' between those translations produced in the US and/or for a primarily North

97 L. Gu, 'Introduction' in Aristotle, Politics, trans. Sachs, p. xliii; H. Rackham, 'Introduction' in Aristotle, Politics, trans. Rackham, p. xii. 
American audience, and those published in Britain, given the divergent histories of democracy in these two contexts. Finally, it would also be interesting to study the manner in which statesmanship is presented in texts translated from other languages - with Latin being an obvious choice - and hence to further develop our understanding of the role of translation in shaping the evolution of this concept as it has travelled across languages and through time. 